Int. J. Dev. Biol. 62: 5-13 (2018)

https://doi.org/10.1387/ijdb.170277rm

\title{
Michael Abercrombie: contact inhibition of locomotion and more
}

\author{
ALICE ROYCROFT and ROBERTO MAYOR* \\ Department of Cell and Developmental Biology, University College London, Gower Street, London, UK.
}

\begin{abstract}
Michael Abercrombie is regarded as one of the principal pioneers of cell biology. Although Abercrombie began his career as an experimental embryologist, working on the avian organizer with C. H. Waddington, questions on how cells in culture migrate and interact dominated his career. Whilst studying the social behaviour of chick heart embryonic fibroblasts, Abercrombie identified a phenomenon whereby colliding cells collapse their protrusions towards the cell-cell contact upon a collision, preventing their continued migration. The cells then form protrusions away from the contact and, space permitting, migrate away from each other. This behaviour is now referred to as 'contact inhibition of locomotion' and has been identified within embryology as the driving force behind the directional migration of the neural crest and the dispersion patterning of haemocytes and Cajal-Retzius neurons. Furthermore, its loss between collisions of cancer cells and healthy cells is associated with metastasis. In this review we begin with an overview of Abercrombie's life and highlight some of his key publications. We then discuss Abercrombie's discovery of contact inhibition of locomotion, the roles which cell-cell adhesions, cell-matrix adhesions and the cytoskeleton play in facilitating this phenomenon, and the importance of contact inhibition of locomotion within the living organism.
\end{abstract}

KEY WORDS: Abercrombie, contact inhibition of locomotion, cell migration, cancer

\section{Introduction}

Michael Abercrombie (1912-1979) is a revered biologist (Fig. 1). Although he began his academic career as an embryologist, he is widely regarded as one of the principal pioneers into the field of cell biology, transforming cell biology from a qualitative science into a quantitative one (Fig. 2). Abercrombie was born in Gloucestershire, UK on $14^{\text {th }}$ August 1912 to the poet and critic Lascelles Abercrombie, who was one of the Dymock Poets (Medawar, 1980). In 1931 Abercrombie attended Queen's College, Oxford where he received a Hastings Scholarship to read Zoology under the tuition of Gavin de Beer. Abercrombie graduated with a first class degree, having chosen embryology as his specialist subject. After graduating Abercrombie worked with $\mathrm{C}$. $\mathrm{H}$. Waddington at the Strangeways Research Laboratory in Cambridge, with the aim to become an experimental embryologist - indeed Abercrombie went on to become one of the founders, and the first editor, of the Journal of Embryology and Experimental Morphology, which later become the prestigious journal Development. During his time with $\mathrm{C}$. H. Waddington, Abercrombie worked on the chick embryo exploring the properties of the avian organizer. By grafting epiblast tissue under the primitive streak of a host embryo when it is in the primitive streak stage, Abercrombie concluded that all parts of the epiblast could be induced to form neural tissue (Abercrombie, 1937). In a similar set of experiments where primitive streak tissue was grafted under the primitive streak of a host embryo, Abercrombie identified that the anterior-posterior axis and regional morphology of the graft would alter to mimic that of the host (Abercrombie and Waddington, 1937). However, it was not just embryology that fascinated Abercrombie but the morphogenetic process - both in embryogenesis and in wound healing, and this interest would stay with Abercrombie throughout his career (Dunn and Jones, 1998). Following his time with $\mathrm{C}$. $\mathrm{H}$. Waddington, Abercrombie became part of a research project investigating peripheral nerve regeneration and wound healing. This project was instigated by J. Z. Young and included his friend Peter Medawar, who later wrote a biographical memoir of Abercrombie for the Royal Society (Medawar, 1980). Abercrombie, in collaboration with his wife M. L. (Jane) Johnson,

Abbreviations used in this paper: CIL, contact inhibition of locomotion. *Address correspondence to: Roberto Mayor. Department of Cell and Developmental Biology, University College London, Gower Street, London WC1E 6BT, UK.
Email: r.mayor@ucl.ac.uk (D) 
studied the behaviour of Schwann cells in tissue culture as they migrated out from pieces of severed peripheral nerve. They observed that Schwann cells and fibroblasts, once they had started dispersing out of the severed tissue, initially demonstrated high migratory activity. However, their motility significantly decreased once the cells became more confluent, mirroring the reduced migration of Schwann cells observed in vivo when stumps of severed nerves were reunited (Abercrombie and Johnson, 1942). Subsequent work demonstrated that a close association between Schwann cells and nerve fibres inhibits the migration of Schwann cells from severed peripheral nerve tissue; when these cells come into contact the migration of Schwann cells is restricted (Abercrombie et al., 1949).

In 1946 Abercrombie gained a position as a lecturer of embryology, and subsequently zoology, at University College London. After a brief period working once again on chick embryos, Abercrombie became dedicated to understanding the behaviour of cells in tissue culture. He was particularly focused on appreciating cell migration, a research field he saw as underappreciated, and cell-cell interactions. Abercrombie was noted as being a 'neat and fastidious worker, technically deft and scrupulously precise' (Medawar, 1980). These qualities allowed Abercrombie not only to succeed as an experimental embryologist but to excel working on tissue culture as well. It was at UCL that Abercrombie began a fruitful collaboration with Joan Heaysman. Together they published a series of papers on the social interactions of cells that were seminal in their use of time-lapse cinematography to generate images that could be quantitatively analysed. These papers, with their careful methodology, control experiments, and statistical analysis, are seen by many as the founding of cell biology as we know it today (Dunn and Jones, 1998). In these papers Abercrombie characterised a migratory phenomenon which is now known as contact inhibition of locomotion (CIL) and is the focus of this review (Abercrombie and Heaysman, 1953, 1954b). In the 1950s and 60s Abercrombie continued working at UCL on understanding the mechanisms that drive CIL and the in vivo relevance of this behaviour. During this time Abercrombie helped to found the Journal of Embryology and

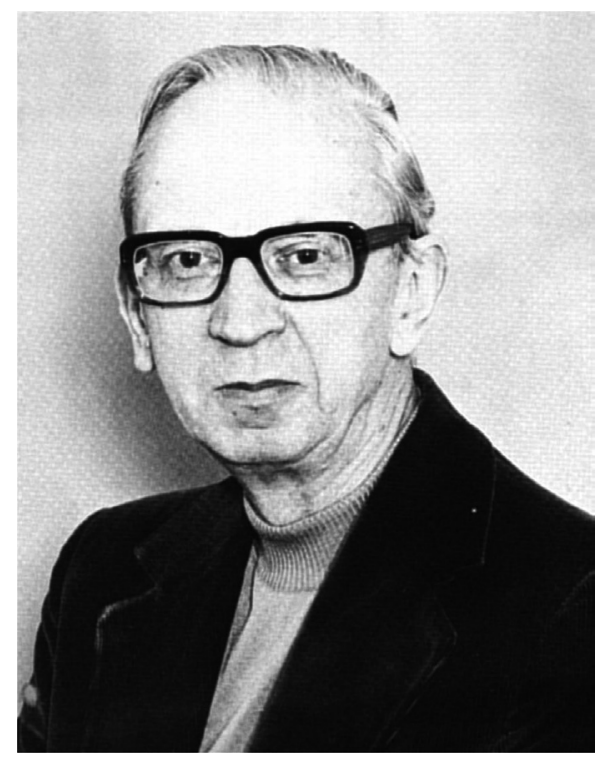

Fig. 1. Michael Abercrombie (1912-1979). Thanks to Prof. Gareth Jones in his capacity as Chair Trustees of the Abercrombie Fund for giving us this photo.
BOX 1: Early description byAbercrombie of the stages of contact inhibition of locomotion (CIL).

'A fibroblast moving on a plane surface, if its forward end is free of other fibroblasts, seems always to be preceded by a pseudopodium [now known as lamellae] in the form of a ruffled membrane. Consequently it is such a membrane which makes contact with other fibroblasts. The contact when established is a close adhesion.. It may be broken if the cells move in different directions, but the strength of the adhesion is manifested by distortion followed by sudden retraction of the adhering cytoplasm and a jerking apart of the cells. In addition to adhesion, a cell whose membrane makes a contact usually suffers three other consequences. First, the ruffling activity of the membrane stops. Second, the membrane, if it was expanding, ceases to expand and may contract. Third, the displacement of the whole cell in the direction of the membrane is checked (contact inhibition).. Contact inhibition seems then to consist of the abolition or reduction of the power of the leading membrane to direct the general cell movement, and hence the assumption of dominance by another membrane, newly arising or previously at a competitive disadvantage, which then redirects the cell.' (Abercrombie and Ambrose, 1958)

Experimental Morphology and was its first editor from 1953 until 1962. By 1970 Abercrombie had moved back to the Strangeways Laboratory, this time as its Director, where he continued working until his death in 1979 (Obituary, 1979). Whilst at the Strangeways Laboratory Abercrombie published a series of papers in collaboration with Heaysman and Pegrum on the 'locomotion of fibroblasts' (Abercrombie et al., 1970a, b, c, 1971, 1972). These papers were at the forefront of cell biology and have been credited as being among the first to identify small discrete regions of adhesion that link the substrate to the fibrillar network within the cell i.e. cell-matrix adhesions crosslinking the substrate to the cytoskeleton (Abercrombie et al., 1971), now known as focal adhesions. Having suffered from Hodgkin's lymphoma in his late teens, Abercrombie died from cancer on $28^{\text {th }}$ May 1979. Now, almost 40 years since Abercrombie's death, his work is still revered and his practise of using time-lapse microscopy with careful quantification forever changed the face of cell biology. A series of 'Abercrombie meetings' has been held in his name every five years since his death with the aim to review major advances in cell motility. In addition the Penguin Dictionary of Biology, which Abercrombie first compiled with C. J. Hickman and M. L. Johnson in 1951, is still being published today.

\section{Discovery of contact inhibition of locomotion}

In order to understand the social behaviour of cells, Abercrombie predominately worked on chick heart embryonic fibroblasts, which he obtained by explanting the ventricles from chick embryos incubated for 7-10 days onto coverslips as small pieces of tissue in nutrient medium. Explants were plated 0.5 to $1 \mathrm{~mm}$ apart. A few hours after explants were plated, cells would start to migrate out of the tissue fragments and their behaviour could be observed, imaged using time-lapse cinematography techniques, and quantitatively analysed with the aim to understand how cells are influenced by other cells in their surroundings. The first of Abercrombie and Heaysman's papers highlighted a huge variability in the velocity of individual cells that was dependent upon the number 
of contacts a cell made with other cells; the higher the number of contacts, the slower the overall velocity of the cell (Abercrombie and Heaysman, 1953). In addition a transient increase in the velocity of a cell was observed immediately prior to a collision and immediately after contact was lost. The follow-up paper highlighted a 'mutual restriction of movement' where a contact with another cell not only led to a reduction in velocity but also resulted in an inhibition of the cells continued movement in its given direction (Abercrombie and Heaysman, 1954b). Abercrombie coined the term 'contact inhibition' to describe this directional inhibition of migration (Abercrombie and Heaysman, 1954b). These papers have been widely attributed as being the first to describe contact inhibition, although, as Abercrombie himself pointed out, Leo Loeb observed this phenotype decades earlier between the haemocytes of horseshoe crabs (Loeb, 1921) (Fig. 3).

\section{Contact inhibition of locomotion is a multistep phe- nomenon}

The fundamental definition of CIL, as this migratory phenomenon is now known, is, in Abercrombie's own words, 'the prohibition, when contact between cells occurred, of continued movement such as would carry one cell over the surface of another' (Abercrombie, 1970). As Abercrombie himself identified (Box 1), CIL consists of multiple stages (Fig. 4): i) initially upon a collision there is an acceleration of cells towards each other and cell-cell adhesions form between the colliding cells. ii) This step is followed by a paralysis in the lamellae and a collapse of protrusions towards the contact. iii) The cells then form new protrusions away from the contact, separate and migrate away from each other. Since Abercrombie's discovery of CIL, this phenomenon has been identified in a variety of cells types. CIL can either occur between cells of the same type, termed homotypic CIL, or between cells of different types, termed heterotypic CIL. Examples of cells that undergo homotypic CIL include neural crest cells (Carmona-Fontaine et al., 2008), haemocytes (Davis et al., 2012), Cajal-Retzius neurons (Villar-Cerviño et al., 2013) and chick heart embryonic fibroblasts as Abercrombie observed (Abercrombie and Heaysman, 1954b). Heterotypic CIL has been observed between neural crest cells and somite cells (Gooday and Thorogood, 1985; Jesuthasan, 1996), neural crest cells and placodes (Theveneau et al., 2013), prostate cancer cells and fibroblasts (Batson et al., 2013), and glial cells and glioblastoma cells (Tanaka et al., 2012).

In the decades following Abercrombie's initial characterisation of CIL (Fig. 3), he worked on trying to elucidate the mechanism behind CIL and on establishing the importance of CIL within the living organism (Abercrombie, 1970). Upon Abercrombie's death in 1979, research on CIL stalled. However, the emergence of CIL as a mechanism behind the migration of the neural crest in vivo in zebrafish and Xenopus has led to increased interest in CIL once more (Carmona-Fontaine et al., 2008; Stramer et al., 2013). In the following sections we will first discuss the molecular mechanisms that have now been identified as playing a role in driving CIL. Second we shall highlight the role CIL plays in vivo both during development and in maintaining healthy tissue in adults.

\section{Molecular mechanisms}

\section{Cell-cell adhesion}

When Abercrombie initially characterised fibroblasts undergoing CIL, he noted that an acceleration was observed immediately after contact when cells collided (Abercrombie and Heaysman,

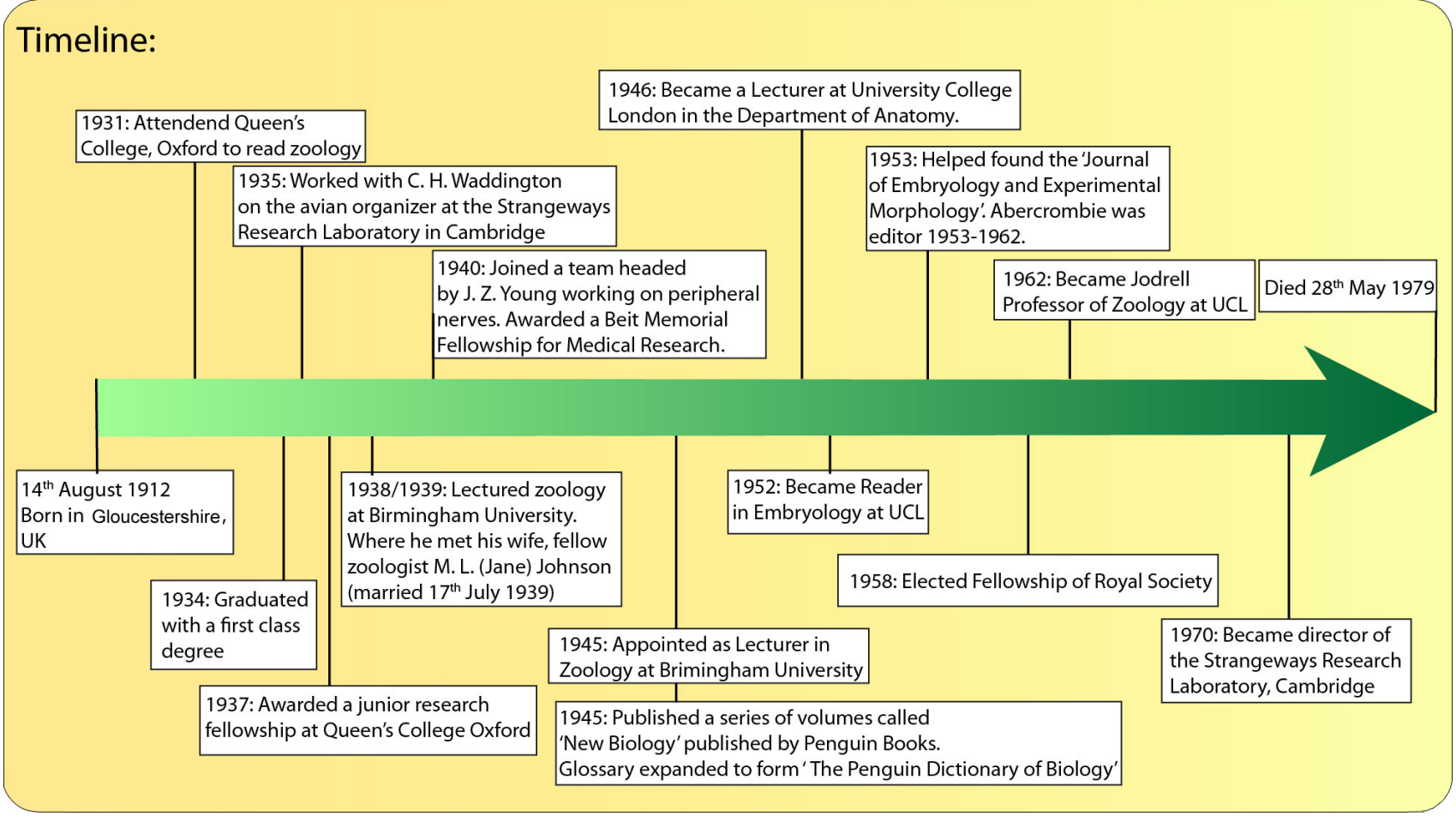

Fig. 2. Timeline of Michael Abercrombie's life. Key dates in Abercrombie's life were compiled from a variety of sources (1979; Bellairs, 2000; Dunn and Jones, 1998; Medawar, 1980). 
1953). This observation has been verified both in vitro and in vivo (Davis et al., 2015; Scarpa et al., 2013) and appears to be due to an increase in the speed of the cells towards each other induced by the lamellae of colliding cells making contact (Davis et al., 2015). Furthermore this acceleration is lost in cells where CIL response in impaired (Davis et al., 2015). Abercrombie also noted that a physical contact occurs between cells undergoing CIL and suggested this contact leads to the formation of an adhesion between the cells (Abercrombie and Heaysman, 1954b). Abercrombie used interference microscopy to try and elucidate the nature of these adhesions (Abercrombie and Ambrose, 1958). He noted that when the lamellae of colliding fibroblasts came in to contact they stopped ruffling. The contacting membrane then retracts and tension is observed across the contact (Abercrombie and Ambrose, 1958; Heaysman and Pegrum, 1973). Abercrombie speculated that this tension across the membranes must be down to the formation of an adhesion between the cells. Although Abercrombie himself could not identify the nature of the adhesions between cells, some of the adhesions involved in driving CIL have since been discovered (Fig. 4). It has become evident that the formation of transient cadherin-based adhesions are involved in driving CIL in multiple cell types (Becker et al., 2013; Bracke et al., 1997; Chen and Obrink, 1991; Huttenlocher et al., 1998; Omelchenko et al., 2001; Scarpa et al., 2015; Tanaka et al., 2012; Theveneau et al., 2010). Cadherins are a large superfamily of calcium dependent adhesion molecules. They were first identi- fied in carcinoma cells as the glycoprotein responsible for strong homophillic adhesion between cells (Yoshida and Takeichi, 1982). Classical cadherins, such as those identified in driving CIL, have a single transmembrane span and mediate the binding of cadherins from neighbouring cells via their $\mathrm{N}$-terminal region (Chen et al., 2005). The C-terminal cytoplasmic domains are highly conserved between classical cadherins and they are responsible for interacting with the cytoskeleton, cytoplasmic proteins such as catenins, and modulating the activity of small GTPases (Dufour et al., 2013; Leckband and de Rooij, 2014). E-cadherin, the first cadherin to be identified and so called due to its predominant expression in epithelial cells, was the first cadherin shown to play a role in CIL when it was identified in L-cells, a fibroblast cell line derived from mice (Chen and Obrink, 1991). In these cells the presence of E-cadherin was shown to inhibit the invasiveness of L-cells by inhibiting migration through paralysis of the lamellae when cells collided (Chen and Obrink, 1991). Following this discovery, E-cadherin has been shown to inhibit protrusive activity and migration in epithelial cells (Bracke et al., 1997), and has been demonstrated as a key player facilitating CIL between carcinoma cells (Ayollo et al., 2009). In addition N-cadherin, so called due its discovery in the neural plate, is required for CIL response in myoblasts (Huttenlocher et al., 1998), glial cells (Tanaka et al., 2012) and neural crest cells (Scarpa et al., 2015; Theveneau et al., 2010). Cadherin-11 has also been shown to play a role in CIL in neural crest cells (Becker et al., 2013). Heterotypic CIL between

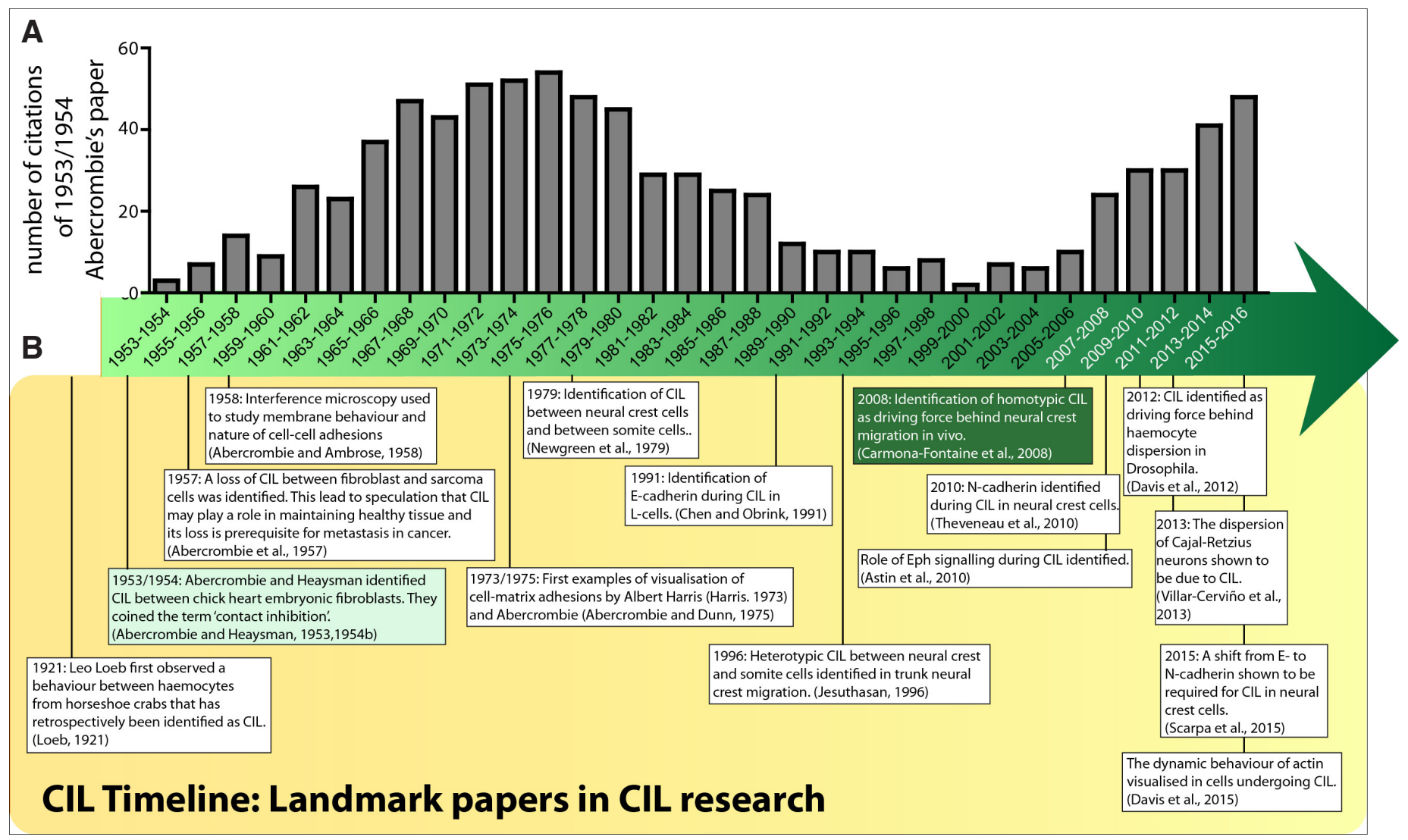

Fig. 3. Contact inhibition of locomotion (CIL) over time. (A) Number of citations for the first two Abercrombie' papers describing CIL (Abercrombie and Heaysman, 1953, 1954b). (B) Timeline of key contact inhibition of locomotion publications. CIL was first observed in 1921 by Leo Loeb (Loeb, 1921) and later characterised by Abercrombie. Here is a timeline indicating some of the key publications on contact inhibition of locomotion. 
epithelial cells and fibroblasts is driven by the formation of heterotypic adhesions of $\mathrm{E}$ - and $\mathrm{N}$-cadherin, where the epithelial cells solely express $\mathrm{E}$ - and the fibroblasts solely express $\mathrm{N}$-cadherin (Omelchenko et al., 2001).

In additional to classical cadherins, Eph receptors have also been implicated in driving CIL (Astin et al., 2010; Batson et al., 2013; Batson et al., 2014; Marston et al., 2003). Eph receptors are a group of tyrosine receptors that bind to transmembrane ephrin ligands from a neighbouring cell and induce bidirectional signalling in both the ligand- and receptor-expressing cell (Kullander and Klein, 2002). Eph-ephrin signalling can result in either a repulsive or attractive response (Poliakov et al., 2004). EphA signalling is required for CIL in prostate cancer cells (Batson et al., 2013; Batson et al., 2014) whereas EphB signalling supresses this response (Astin et al., 2010; Batson et al., 2013). However, EphB signalling induces a CIL response upon a collision in MTIn3 cells, a highly invasive breast adenoacarinoma cell line (Lin et al., 2015), and fibroblasts (Marston et al., 2003). Interestingly both EphA and EphB signalling is required for CIL in Cajal-Retzius neurons (Villar-Cerviño et al., 2013). There is evidence of cadherin-Eph signalling crosstalk in heterotypic CIL between glial and glioblastoma cells (Tanaka et al., 2012). Upon a collision N-cadherin stimulates a CIL response through its association with the nucleotide diphosphate kinase Nm23-H1 (Tanaka et al., 2012). Nm23-H1 localises to $\mathrm{N}$-cadherin where it binds Tiam1, a guanine exchange factor involved in the activation of Rac1, and blocks Tiam1 from activating Rac1 near the cell-cell contact. However, the expression of ephrin-B1 supresses CIL by blocking the association of Nm23-H1 with Tiam1 and thus elevates the activity of Tiam1 and consequently Rac1 at the cell-cell contact (Tanaka et al., 2012). In order for CIL to occur, a co-ordinated response is likely to be required between cadherin-based adhesions and Eph receptors such as that which occurs during embryonic boundary formation in Xenopus mesoderm (Fagotto et al., 2013).

A recent paper modelling CIL between cells on 1-dimensional lines has highlighted the importance of tightly controlled cellcell adhesion strength for CIL to occur (Kulawiak et al., 2016). Increased adhesions can lead to the formation of chains of cells where cells no longer separate after colliding (Desai et al., 2013; Kulawiak et al., 2016).

\section{Cell-matrix adhesions}

Cell-matrix adhesions are large multi-protein complexes that couple the extracellular matrix to the actin cytoskeleton thus creating traction which facilitates cell migration (Alexandrova et al., 2008; Gardel et al., 2010). Abercrombie speculated about the dynamic behaviour of cell-matrix adhesions during CIL in 1970 (Abercrombie, 1970). However, it was not Abercrombie but Harris who first attempted to elucidate their behaviour during CIL (Harris, 1973). Harris used a crude technique to infer the presence of attachment to the substrate. A capillary was inserted between the cell and the substrate and, with the use of micromanipulation and time-lapse cinematography, the regions where the cell was attached to the substrate were revealed (Rappaport and Rappaport, 1968). Using this technique Harris concluded that a detachment of the cell-matrix adhesions in the lamellae occurs upon a collision resulting in the transfer of tension to the cell-cell contact and the subsequent cell-cell separation (Harris, 1973). However, when Abercrombie himself came to investigate the behaviour of the cell-matrix adhesions in the colliding lamellae using interference reflection microscopy, he observed a conflicting result (Abercrombie and Dunn, 1975). Interference reflection microscopy assumes that the regions where the cell membrane is closest to the substrate is where the cell-matrix adhesions are located (Curtis, 1964).

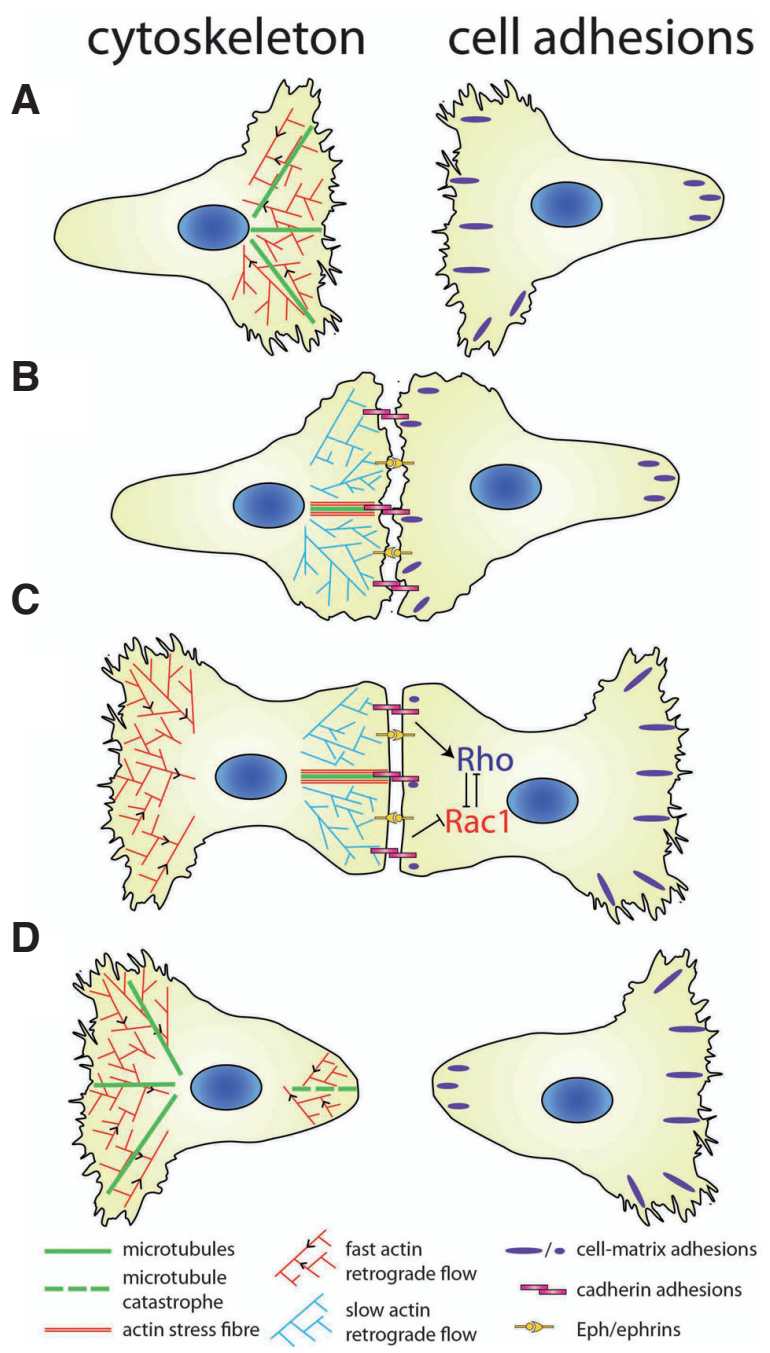

Fig. 4. Role of cytoskeleton and cell-cell adhesions in contact inhibition of locomotion. Illustration of the stages of contact inhibition of locomotion. Cytoskeleton rearrangements are illustrated in the left-hand cell whilst the adhesions involved and how they change is illustrated in the right-hand cell. (A) Freely migrating cells show actin driven protrusions stabilised by microtubules. Cells have large cell-matrix adhesions in their leading edge. (B) Upon a collision cadherin-based adhesions form between cells. Eph receptors bind to ephrin from the colliding cell partner and protrusions start to collapse. Actin flow is reduced and an actin stress fibre and microtubule bundles form, these are aligned between colliding cells. Cell-matrix adhesions begin to disassembly near to the cell-cell contact. (C) Eph/ephrin signalling and cadherin-based adhesions lead to Rho activation and Rac inhibition at the cell-cell contact. Protrusions towards the contact completely collapse. Actin based protrusions develop away from the contact as the cells repolarise. Cell-matrix adhesions begin to enlarge in these new protrusions. (D) The cells eventually separate thanks to the disassembly of large cell-matrix adhesions near the contact, the actin stress fibre and microtubule catastrophe events. Microtubules form in the new leading edge stabilising protrusions. 
Using this technique, Abercrombie observed the persistence of cell-matrix adhesions near the cell-cell contact during a collision and concluded that these adhesions are not lost even at the stage when the contacting lamellae starts to contract. Furthermore he disagreed with Harris that a transfer of tension was occurring across the cell-cell contact solely due to any loss in adhesion to the substrate and insisted a more active mechanism was leading to the build-up of tension across the contact (Abercrombie and Dunn, 1975). Evidence in neural crest cells suggest a disassembly of cell-matrix adhesions near the cell-cell contact occurs prior to separation (Scarpa et al., 2015). However, the loss of cell-matrix adhesions at the contact alone is insufficient to induce separation. The repolarisation of the cells away from the contact and the generation of new protrusions, cell-matrix adhesions and the traction forces they generate in the free edge are also required to induce cell separation (Scarpa et al., 2015; Theveneau et al., 2013). In agreement with the idea that cell-matrix adhesions are lost near to the cell-cell contacts and form in the free edge during CIL, recent computational models have supported a mechanical crosstalk between cell-cell adhesions and cell-matrix adhesions and highlighted that traction forces are predominantly generated at the periphery of cell clusters (Coburn et al., 2016; Zimmermann et al., 2016). In addition these models support the hypothesis that the reduction of cell-matrix adhesions, and consequently traction, near the cell-cell contacts, together with protrusion formation into the free space, could be sufficient to induce CIL (Zimmermann et al., 2016).

In addition to the adhesive nature of cell-matrix adhesions, their assembly induces integrin signalling. Integrin signalling has been implicated in driving a CIL like response in myoblasts (Huttenlocher et al., 1998). When either $\alpha 5$ integrin, $\beta 1$ integrin, or the downstream effectors of integrin signalling paxillin or FAK were ectopically expressed in myoblasts lamellae activity was lost at the cell-cell contact, a hallmark of CIL. However, these cells did not repolarise away from the contact and migrate away from each other but instead remained aggregated together (Huttenlocher et al., 1998). It is likely that cell-matrix adhesions play multiple roles in CIL. Integrin signalling could initially be inducing the paralysis of the lamellae observed upon a collision required for the first step of CIL. However, their disassembly near the contact appears to be required in order for the separation phase of CIL to be induced. Further investigation into the role cell-matrix adhesions play in CIL is required to try and separate their adhesive role from their signalling role to determine how they are involved in driving CIL.

In addition to integrin-based cell-matrix adhesions, syndecan-4, a transmembrane heparan sulphate proteoglycan that crosslinks the extracellular matrix to the actin cytoskeleton via the adapter protein $\alpha$-actinin (Greene et al., 2003), has also been implicated in CIL (Matthews et al., 2008). In the absence of syndecan-4 colliding neural crest cells no longer exhibit lamellae paralysis at the cellcell contact upon a collision, instead they demonstrate elevated levels of Rac1 activity across the whole cell periphery (Matthews et al., 2008). This suggests syndecan-4 supresses the activity of Rac1, although how it is doing so is unclear. In fibroblasts it has been demonstrated that syndecan-4 regulates Rac1 activity via PKC $\alpha$ which it localises to the leading edge (Bass et al., 2007). It is possible a similar mechanism is occurring during CIL in the neural crest. Syndecan-4 has also been shown to interact with cadherin-11 and stimulate the formation of integrin-based cell- matrix adhesions in the free edge of neural crest cells (Langhe et al., 2016). Taken with the growing evidence that syndecan-4 is involved in facilitating crosstalk between cell-cell and cell-matrix adhesions (Gopal et al., 2017), it is likely to be playing a similar role in CIL in the neural crest where the formation of cell-cell adhesions at the contact stimulates the formation of cell-matrix adhesions in the free edge (Theveneau et al., 2013).

\section{Cytoskeleton}

The importance of both cell-cell adhesions and cell-matrix adhesions in facilitating CIL is evident. Both these structures directly crosslink to actin and regulate the dynamic behaviour of the cytoskeleton. It is therefore evident that cytoskeletal rearrangements are fundamental in CIL. Unsurprisingly Abercrombie never identified the role of the cytoskeleton in driving CIL; cellular actin was first visualised directly the year before Abercrombie's death (Taylor and Wang, 1978). However, vast improvements in live-cell imaging have allowed the dynamics of both microtubules and actin to be visualised in cells undergoing $\mathrm{CIL}$ and have highlighted the importance of both of these components in facilitating CIL (Fig. 4) (Davis et al., 2015; Kadir et al., 2011; Moore et al., 2013). In freely migrating cells microtubules stabilise the leading edge of the cell and drive directional migration through their ability to promote lamellipodia formation and inhibit contractility at the leading edge (Bershadsky et al., 1991; Small et al., 2002). Haemocytes undergoing CIL demonstrate highly dynamic microtubules in the lamellar and stable microtubule bundles more centrally that stabilise the protrusions (Stramer et al., 2010). When the haemocytes collide the microtubule bundles from the colliding cells align and a sudden deceleration in the cells is observed (Davis et al., 2015; Stramer et al., 2010). Concurrently actin retrograde flow slows in the leading edge upon a collision and actin stress fibres form alongside the microtubule bundles (Davis et al., 2015). When the cells separate a sudden increase in the rate of actin retrograde flow is observed and the microtubule bundle collapses (Davis et al., 2015; Stramer et al., 2010). There is also evidence in fibroblasts and neural crest cells that an increase in the frequency of microtubule dynamics and catastrophe events is required at the contact to promote cell separation (Kadir et al., 2011; Moore et al., 2013). In addition new microtubules must also form at the free edge in order to induce separation (Kadir et al., 2011).

The small GTPases are regulators of the cytoskeletal network and are involved in promoting reorganisations of the cytoskeleton such as those described above. It is therefore unsurprising that the activity of Rac1 and Rho have also been implicated in regulating CIL (Roycroft and Mayor, 2016; Theveneau and Mayor, 2010). While there is much work on the regulatory pathways leading to localised changed in Rac1 and Rho activity during CIL (Anear and Parish, 2012; Fritz et al., 2015; Matthews et al., 2008; Roycroft and Mayor, 2016; Scarpa et al., 2015; Theveneau and Mayor, 2010), the overall effect is that Rac1 activity is initially elevated in the leading edge of the cell. Upon a collision Rac1 activity is suppressed near the contact and Rho activity is stimulated. Rac1 is them stimulated in the free edge driving the repolarisation and eventual separation of the cells.

Overall CIL is a multifaceted process that involves the coordinated regulation of multiple components. While Abercrombie himself tried to elucidate some of these mechanisms, 60 years after its initial characterisation we are still trying to understand 
this complex phenomenon.

\section{Role of contact inhibition of locomotion in vivo}

Upon identifying CIL between chick heart embryonic fibroblasts, Abercrombie, speculated on its importance within living organisms. He hypothesised that CIL may be involved in driving re-epithelisation in wound healing where wounding breaks the cell-cell contact and creates a free space (Abercrombie, 1979). CIL would allow cells to produce protrusions into the free space and migrate into it. Abercrombie also suggested a role for CIL in maintaining cells in a stationary state within a healthy tissue; the loss of CIL, he hypothesised, could lead to cells becoming invasive (Abercrombie, 1979; Abercrombie and Heaysman, 1954a; Abercrombie et al., 1957). The same year that Abercrombie and Heaysman published their paper characterising CIL, they published a follow-up paper demonstrating that heterotypic CIL does notoccur between healthy fibroblasts and sarcoma cells (Abercrombie and Heaysman, 1954a); instead of lamellae paralysis and repolarising upon a collision with fibroblasts, sarcoma cells continued migrating in their given direction. A more thorough paper was published a few years later quantifying this observation as the third part of their 'social behaviour' series (Abercrombie et al., 1957). Abercrombie was fascinated in understanding the importance of CIL in vivo and this interest stayed with him for the remainder of his life. In fact a paper written by Abercrombie on the role of CIL in malignancy was posthumously published a few months after his death (Abercrombie, 1979). In the decades following Abercrombie's death CIL became an unappreciated subject. However, in the past decade CIL has experienced a resurgence of interest (Fig. 3A). CIL and its loss towards healthy cells has now been demonstrated in prostate cancer cells (Astin et al., 2010; Batson et al., 2013; Batson et al., 2014), and adenocarcinoma cells (Lin et al., 2015) supporting Abercrombie's hypothesis that CIL plays a role in maintaining healthy tissue and its loss may drive metastasis (Parish et al., 1987; Tanaka et al., 2012).

In addition to the role of CIL in preventing metastasis, CIL has been identified during embryo development (Carmona-Fontaine et al., 2008; Davis et al., 2012; Stramer and Mayor, 2016; Stramer et al., 2013). Neural crest and somite cells were shown to undergo heterotypic CIL when cultured in vitro (Gooday and Thorogood, 1985; Newgreen et al., 1979). There is evidence in vivo that CIL between somite and neural crest cells help guide the migration of the trunk neural crest (Jesuthasan, 1996). Cranial neural crest cells have since been imaged undergoing CIL in vivo in Xenopus and Zebrafish (Carmona-Fontaine et al., 2008; Theveneau et al., 2010) which led to the discovery that CIL between neural crest cells is required for their directional collective migration within the embryo (Carmona-Fontaine et al., 2008; Theveneau et al., 2010; Theveneau et al., 2013; Woods et al., 2014). Further to the homotypic CIL between neural crest cells, heterotypic CIL between neural crest cells and placodes is also essential for the migration of the neural crest in vivo (Theveneau et al., 2013). Although the role of CIL in collective migration in vivo has predominantly been studied in the neural crest, one can speculate that it may play a similar role in the migration of other cell types, such as the contactdependent polarity observed in the migration of border cells in the Drosophila ovary (Cai et al., 2014).

As Leo Loeb observed in the 1920s, CIL also occurs between haemocytes (Davis et al., 2012; Loeb, 1921). Haemocytes are large highly migratory macrophages involved in the immune response. In Drosophila haemocytes migrate out from the head mesoderm before dispersing throughout the embryo via defined routes (Tepass et al., 1994). It has been revealed that the precise three-line dispersion pattern that haemocytes form within the embryo is a consequence of CIL (Davis et al., 2012). The regular dispersion of Cajal-Retzius neurons throughout the cortex has also been identified as a consequence of CIL in mouse embryos (Villar-Cerviño et al., 2013). It is highly likely that CIL plays a similar role in driving dispersion patterning in other cell types within the developing embryo (Kay et al., 2012; Stramer and Mayor, 2016).

\section{Concluding remarks}

Abercrombie was a true biologist; his work both as an experimental embryologist and cell biologist is held in high regard. When working on cell biology Abercrombie never lost sight of trying to understand how the phenomena he observed in cells in culture translated to the living organism. It would be wrong to remember Abercrombie for his discovery of CIL alone, however, his work on this field was fundamental in helping shape our understanding both of cell motility and the ways cells interact. Following Abercrombie's death, CIL was all but ignored. However, now, largely due to its discovery within the embryo, the field of $\mathrm{CIL}$ is thriving. While only a limited number of migratory events are attributed to CIL in vivo, it is likely to be a conserved mechanism involved in driving directional collective migration and dispersion within other cell types.

\section{Acknowledgements}

Work in RM lab is supported by grants from Medical Research Council (M010465 and J000655), Biotechnology and Biological Sciences Research Council (M008517) and Wellcome Trust to R. Mayor.

\section{References}

ABERCROMBIE, M. (1937). The behaviour of epiblast grafts beneath the primitivestreak of the chick. J. Exp. Biol. 14: 302-318.

ABERCROMBIE, M. (1970). Contact inhibition in tissue culture. In Vitro 6: 128-142. ABERCROMBIE, M. (1979). Contact inhibition and malignancy. Nature 281:259-262.

ABERCROMBIE, M. and AMBROSE, E.J. (1958). Interference microscope studies of cell contacts in tissue culture. Exp Cell Res 15: 332-345.

ABERCROMBIE, M. and DUNN, G.A. (1975). Adhesions of fibroblasts to substratum during contact inhibition observed by interference reflection microscopy. Exp Cell Res 92: 57-62.

ABERCROMBIE, M. and HEAYSMAN, J.E. (1953). Observations on the social behaviour of cells in tissue culture. I. Speed of movement of chick heart fibroblasts in relation to their mutual contacts. Exp Cell Res 5: 111-131.

ABERCROMBIE, M. and HEAYSMAN, J.E. (1954a). Invasiveness of sarcoma cells. Nature 174: 697-698.

ABERCROMBIE, M. and HEAYSMAN, J.E. (1954b). Observations on the socia behaviour of cells in tissue culture. II. Monolayering of fibroblasts. Exp Cell Res 6: 293-306.

ABERCROMBIE, M., HEAYSMAN, J.E. and KARTHAUSER, H.M. (1957). Social behaviour of cells in tissue culture. III. Mutual influence of sarcoma cells and fibroblasts. Exp Cell Res 13: 276-291.

ABERCROMBIE, M., HEAYSMAN, J.E. and PEGRUM, S.M. (1970a). The locomotion of fibroblasts in culture. 3. Movements of particles on the dorsal surface of the leading lamella. Exp Cell Res 62: 389-398.

ABERCROMBIE, M., HEAYSMAN, J.E. and PEGRUM, S.M. (1970b). The locomotion of fibroblasts in culture. I. Movements of the leading edge. Exp Cell Res 59:393-398. 
ABERCROMBIE, M., HEAYSMAN, J.E. and PEGRUM, S.M. (1970c). The locomotion of fibroblasts in culture. II. "Ruffling". Exp Cell Res 60: 437-444.

ABERCROMBIE, M., HEAYSMAN, J.E. and PEGRUM, S.M. (1971). The locomotion of fibroblasts in culture. IV. Electron microscopy of the leading lamella. Exp Cell Res 67: 359-367.

ABERCROMBIE, M., HEAYSMAN, J.E. and PEGRUM, S.M. (1972). Locomotion of fibroblasts in culture. V. Surface marking with concanavalin A. Exp Cell Res 73: 536-539.

ABERCROMBIE, M. and JOHNSON, M.L. (1942). The outwandering of cells in tissue cultures of nerves undergoing Wallerian degeneration. J. Exp. Biol. 19: 266-283.

ABERCROMBIE, M., JOHNSON, M.L. and THOMAS, G.A. (1949). The influence of nerve fibres on Schwann cell migration investigated in tissue culture. Proc $R$ Soc Lond B Biol Sci 136: 448-460.

ABERCROMBIE, M. and WADDINGTON, C.H. (1937). The behaviour of grafts of primitive streak beneath the primitive streak of the chick. J. Exp. Biol. 14:319-334.

ALEXANDROVA, A.Y., ARNOLD, K., SCHAUB, S., VASILIEV, J.M., MEISTER, J.J., BERSHADSKY, A.D. and VERKHOVSKY, A.B. (2008). Comparative dynamics of retrograde actin flow and focal adhesions: formation of nascent adhesions triggers transition from fast to slow flow. PLoS One 3: e3234.

ANEAR, E. and PARISH, R.W. (2012). The effects of modifying RhoA and Rac1 activities on heterotypic contact inhibition of locomotion. FEBS Lett 586: 1330-1335.

ASTIN, J.W., BATSON, J., KADIR, S., CHARLET, J., PERSAD, R.A., GILLATT, D., OXLEY, J.D. and NOBES, C.D. (2010). Competition amongst Eph receptors regulates contact inhibition of locomotion and invasiveness in prostate cancer cells. Nat Cell Biol 12: 1194-1204.

AYOLLO, D.V., ZHITNYAK, I.Y., VASILIEV, J.M. and GLOUSHANKOVA, N.A. (2009). Rearrangements of the actin cytoskeleton and E-cadherin-based adherens junctions caused by neoplasic transformation change cell-cell interactions. PLoS One 4: e8027.

BASS, M.D., ROACH, K.A., MORGAN, M.R., MOSTAFAVI-POUR, Z., SCHOEN, T., MURAMATSU, T., MAYER, U., BALLESTREM, C., SPATZ, J.P. and HUMPHRIES, M.J. (2007). Syndecan-4-dependent Rac1 regulation determines directional migration in response to the extracellular matrix. J Cell Biol 177: 527-538.

BATSON, J., ASTIN, J.W. and NOBES, C.D. (2013). Regulation of contact inhibition of locomotion by Eph-ephrin signalling. J Microsc 251: 232-241.

BATSON, J., MACCARTHY-MORROGH, L., ARCHER, A., TANTON, H. and NOBES, C.D. (2014). EphA receptors regulate prostate cancer cell dissemination through Vav2-RhoA mediated cell-cell repulsion. Biol Open 3: 453-462.

BECKER, S.F., MAYOR, R. and KASHEF, J. (2013). Cadherin-11 mediates contact inhibition of locomotion during Xenopus neural crest cell migration. PLOS One 8: e85717.

BELLAIRS, R. (2000). Michael Abercrombie (1912-1979). Int J Dev Biol 44: 23-28.

BERSHADSKY, A.D., VAISBERG, E.A. and VASILIEV, J.M. (1991). Pseudopodial activity at the active edge of migrating fibroblast is decreased after drug-induced microtubule depolymerization. Cell Motil Cytoskeleton 19: 152-158.

BRACKE, M.E., DEPYPERE, H., LABIT, C., VAN MARCK, V., VENNEKENS, K., VERMEULEN, S.J., MAELFAIT, I., PHILIPPÉ, J., SERREYN, R. and MAREEL, M.M. (1997). Functional downregulation of the E-cadherin/catenin complex leads to loss of contact inhibition of motility and of mitochondrial activity, but not of growth in confluent epithelial cell cultures. Eur J Cell Biol 74: 342-349.

CAI, D., CHEN, S.C., PRASAD, M., HE, L., WANG, X., CHOESMEL-CADAMURO, V., SAWYER, J.K., DANUSER, G. and MONTELL, D.J. (2014). Mechanical feedback through E-cadherin promotes direction sensing during collective cell migration. Cell 157: 1146-1159.

CARMONA-FONTAINE, C., MATTHEWS, H.K., KURIYAMA, S., MORENO, M., DUNN, G.A., PARSONS, M., STERN, C.D. and MAYOR, R. (2008). Contact inhibition of locomotion in vivo controls neural crest directional migration. Nature 456:957-961.

CHEN, C.P., POSY, S., BEN-SHAUL, A., SHAPIRO, L. and HONIG, B.H. (2005). Specificity of cell-cell adhesion by classical cadherins: Critical role for low-affinity dimerization through beta-strand swapping. Proc NatlAcad Sci. USA 102:8531-8536.

CHEN, W.C. and OBRINK, B. (1991). Cell-cell contacts mediated by E-cadherin (uvomorulin) restrict invasive behavior of L-cells. J Cell Biol 114: 319-327.

COBURN, L., LOPEZ, H., CALDWELL, B.J., MOUSSA, E., YAP, C., PRIYA, R., NOPPE, A., ROBERTS, A.P., LOBASKIN, V., YAP, A.S., NEUFELD, Z. and GOMEZ, G.A. (2016). Contact inhibition of locomotion and mechanical cross-talk between cell-cell and cell-substrate adhesion determine the pattern of junctional tension in epithelial cell aggregates. Mol Biol Cell 27: 3436-3448.

CURTIS, A.S. (1964). The mechanism of adhesion of cells to glass. A study by interference reflection microscopy. J Cell Biol 20: 199-215.

DAVIS, J.R., HUANG, C.Y., ZANET, J., HARRISON, S., ROSTEN, E., COX, S. SOONG, D.Y., DUNN, G.A. and STRAMER, B.M. (2012). Emergence of embryonic pattern through contact inhibition of locomotion. Development 139: 4555-4560.

DAVIS, J.R., LUCHICI, A., MOSIS, F., THACKERY, J., SALAZAR, J.A., MAO, Y., DUNN, G.A., BETZ, T., MIODOWNIK, M. and STRAMER, B.M. (2015). Intercellular forces orchestrate contact inhibition of locomotion. Cell 161: 361-373.

DESAI, R.A., GOPAL, S.B., CHEN, S. and CHEN, C.S. (2013). Contact inhibition of locomotion probabilities drive solitary versus collective cell migration. $J$ R Soc Interface 10: 20130717.

DUFOUR, S., MĖGE, R.M. and THIERY, J.P. (2013). $\alpha$-catenin, vinculin, and F-actin in strengthening E-cadherin cell-cell adhesions and mechanosensing. Cell Adh Migr 7: 345-350.

DUNN, G. and JONES, G. (1998). Michael Abercrombie: the pioneer ethologist of cells. Trends Cell Biol 8: 124-126.

FAGOTTO, F., ROHANI, N., TOURET, A.S. and LI, R. (2013). A molecular base for cell sorting at embryonic boundaries: contact inhibition of cadherin adhesion by ephrin/ Eph-dependent contractility. Dev Cell 27: 72-87.

FRITZ, R.D., MENSHYKAU, D., MARTIN, K., REIMANN, A., PONTELLI, V. and PERTZ, O. (2015). SrGAP2-Dependent Integration of Membrane Geometry and Slit-Robo-Repulsive Cues Regulates Fibroblast Contact Inhibition of Locomotion. Dev Cell 35: 78-92.

GARDEL, M.L., SCHNEIDER, I.C., ARATYN-SCHAUS, Y. and WATERMAN, C.M. (2010). Mechanical integration of actin and adhesion dynamics in cell migration. Annu Rev Cell Dev Biol 26: 315-333.

GOODAY, D. and THOROGOOD, P. (1985). Contact behaviour exhibited by migrating neural crest cells in confrontation culture with somitic cells. Cell Tissue Res 241: $165-169$.

GOPAL, S., MULTHAUPT, H.A.B., POCOCK, R. and COUCHMAN, J.R. (2017) Cell-extracellular matrix and cell-cell adhesion are linked by syndecan-4. Matrix Biol 60-61: 57-69.

GREENE, D.K., TUMOVA, S., COUCHMAN, J.R. and WOODS, A. (2003). Syndecan-4 associates with alpha-actinin. J Biol Chem 278: 7617-7623.

HARRIS,A. (1973). Location of cellular adhesions to solid substrata. Dev Bio/35: 97-114.

HEAYSMAN, J.E. and PEGRUM, S.M. (1973). Early contacts between fibroblasts. An ultrastructural study. Exp Cell Res 78: 71-78.

HUTTENLOCHER, A., LAKONISHOK, M., KINDER, M., WU, S., TRUONG, T., KNUDSEN, K.A. and HORWITZ, A.F. (1998). Integrin and cadherin synergy regulates contact inhibition of migration and motile activity. J Cell Biol 141: 515-526.

JESUTHASAN, S. (1996). Contact inhibition/collapse and pathfinding of neural crest cells in the zebrafish trunk. Development 122: 381-389.

KADIR, S., ASTIN, J.W., TAHTAMOUNI, L., MARTIN, P. and NOBES, C.D. (2011). Microtubule remodelling is required for the front-rear polarity switch during contact inhibition of locomotion. J Cell Sci 124: 2642-2653.

KAY, J.N., CHU, M.W. and SANES, J.R. (2012). MEGF10 and MEGF11 mediate homotypic interactions required for mosaic spacing of retinal neurons. Nature 483: 465-469.

KULAWIAK, D.A., CAMLEY, B.A. and RAPPEL, W.J. (2016). Modeling Contact Inhibition of Locomotion of Colliding Cells Migrating on Micropatterned Substrates. PLoS Comput Biol 12: e1005239.

KULLANDER, K. and KLEIN, R. (2002). Mechanisms and functions of Eph and ephrin signalling. Nat Rev Mol Cell Biol 3: 475-486.

LANGHE, R.P., GUDZENKO, T., BACHMANN, M., BECKER, S.F., GONNERMANN, C., WINTER, C., ABBRUZZESE, G., ALFANDARI, D., KRATZER, M.C., FRANZ, C.M. and KASHEF, J. (2016). Cadherin-11 localizes to focal adhesions and promotes cell-substrate adhesion. Nat Commun 7: 10909.

LECKBAND, D.E. and DE ROOIJ, J. (2014). Cadherin adhesion and mechanotransduction. Annu Rev Cell Dev Biol 30: 291-315.

LIN, B., YIN, T., WU, Y.I., INOUE, T. and LEVCHENKO, A. (2015). Interplay between chemotaxis and contact inhibition of locomotion determines exploratory cell migration. Nat Commun 6: 6619 . 
LOEB, L. (1921). Amoeligboid movement, tissue formation and consistency of protoplasm. Science 53: 261-262.

MARSTON, D.J., DICKINSON, S. and NOBES, C.D. (2003). Rac-dependent transendocytosis of ephrinBs regulates Eph-ephrin contact repulsion. Nat Cell Biol 5: 879-888.

MATTHEWS, H.K., MARCHANT, L., CARMONA-FONTAINE, C., KURIYAMA, S. LARRAÍN, J., HOLT, M.R., PARSONS, M. and MAYOR, R. (2008). Directional migration of neural crest cells in vivo is regulated by Syndecan-4/Rac1 and noncanonical Wnt signaling/RhoA. Development 135: 1771-1780.

MEDAWAR, P. (1980). Michael Abercrombie. 14 August 1912 - 28 May 1979. Biogr. Mems Fell. R. Soc. 26: 1-15.

MOORE, R., THEVENEAU, E., POZZI, S., ALEXANDRE, P., RICHARDSON, J., MERKS, A., PARSONS, M., KASHEF, J., LINKER, C. and MAYOR, R. (2013). Par3 controls neural crest migration by promoting microtubule catastrophe during contact inhibition of locomotion. Development 140: 4763-4775.

NEWGREEN, D.F., RITTERMAN, M. and PETERS, E.A. (1979). Morphology and behaviour of neural crest cells of chick embryo in vitro. Cell Tissue Res 203: 115-140.

Obituary. (1979). Michael Abercrombie 14 August 1912 to 28 May 1979. J Embryol Exp Morphol 54, 1-3.

OMELCHENKO, T., FETISOVA, E., IVANOVA, O., BONDER, E.M., FEDER, H., VASILIEV, J.M. and GELFAND, I.M. (2001). Contact interactions between epitheliocytes and fibroblasts: formation of heterotypic cadherin-containing adhesion sites is accompanied by local cytoskeletal reorganization. Proc Natl Acad Sci USA 98: 8632-8637.

PARISH, R.W., SCHMIDHAUSER, C., SCHMIDT, T. and DUDLER, R.K. (1987). Mechanisms of tumour cell metastasis. J Cell Sci Supp/ 8: 181-197.

POLIAKOV, A., COTRINA, M. and WILKINSON, D.G. (2004). Diverse roles of eph receptors and ephrins in the regulation of cell migration and tissue assembly. Dev Cell 7: 465-480.

RAPPAPORT, R. and RAPPAPORT, B.N. (1968). An analysis of cytokinesis in cultured newt cells. J Exp Zool 168: 187-195.

ROYCROFT, A. and MAYOR, R. (2016). Molecular basis of contact inhibition of locomotion. Cell Mol Life Sci 73: 1119-1130.

SCARPA, E., ROYCROFT, A., THEVENEAU, E., TERRIAC, E., PIEL, M. and MAYOR, R. (2013). A novel method to study contact inhibition of locomotion using micropatterned substrates. Biol Open 2: 901-906.

SCARPA, E., SZABÓ, A., BIBONNE, A., THEVENEAU, E., PARSONS, M. and MAYOR, R. (2015). Cadherin Switch during EMT in Neural Crest Cells Leads to Contact Inhibition of Locomotion via Repolarization of Forces. Dev Cell 34: 421-434
SMALL, J.V., GEIGER, B., KAVERINA, I. and BERSHADSKY, A. (2002). How do microtubules guide migrating cells? Nat Rev Mol Cell Biol 3: 957-964

STRAMER, B. and MAYOR, R. (2017). Mechanisms and in vivo functions of contact inhibition of locomotion. Nat Rev Mol Cell Biol. 18: 43-55

STRAMER, B., MOREIRA, S., MILLARD, T., EVANS, I., HUANG, C.Y., SABET, O. MILNER, M., DUNN, G., MARTIN, P. and WOOD, W. (2010). Clasp-mediated microtubule bundling regulates persistent motility and contact repulsion in Drosophila macrophages in vivo. J Cell Biol 189: 681-689.

STRAMER, B.M., DUNN, G.A., DAVIS, J.R. and MAYOR, R. (2013). Rediscovering contact inhibition in the embryo. J Microsc 251: 206-211.

TANAKA, M., KURIYAMA, S. and AIBA, N. (2012). Nm23-H1 regulates contact inhibition of locomotion, which is affected by ephrin-B1. J Cell Sci 125: 4343-4353.

TAYLOR, D.L. and WANG, Y.L. (1978). Molecular cytochemistry: incorporation of fluorescently labeled actin into living cells. Proc Natl Acad Sci. USA 75: 857-861.

TEPASS, U., FESSLER, L.I., AZIZ, A. and HARTENSTEIN, V. (1994). Embryonic origin of hemocytes and their relationship to cell death in Drosophila. Development 120: 1829-1837.

THEVENEAU, E., MARCHANT, L., KURIYAMA, S., GULL, M., MOEPPS, B., PARSONS, M. and MAYOR, R. (2010). Collective chemotaxis requires contact-dependent cell polarity. Dev Cell 19: 39-53.

THEVENEAU, E. and MAYOR, R. (2010). Integrating chemotaxis and contact-inhibition during collective cell migration: Small GTPases at work. Small GTPases 1:113-117

THEVENEAU, E., STEVENTON, B., SCARPA, E., GARCIA, S., TREPAT, X., STREIT, A. and MAYOR, R. (2013). Chase-and-run between adjacent cell populations promotes directional collective migration. Nat Cell Biol 15: 763-772.

VILLAR-CERVIÑO, V., MOLANO-MAZÓN, M., CATCHPOLE, T., VALDEOLMILLOS, M., HENKEMEYER, M., MARTÍNEZ, L.M., BORRELL, V. and MARÍN, O. (2013). Contact repulsion controls the dispersion and final distribution of Cajal-Retzius cells. Neuron 77: 457-471.

WOODS, M.L., CARMONA-FONTAINE, C., BARNES, C.P., COUZIN, I.D., MAYOR, R. and PAGE, K.M. (2014). Directional collective cell migration emerges as a property of cell interactions. PLoS One 9: e104969.

YOSHIDA, C. and TAKEICHI, M. (1982). Teratocarcinoma cell adhesion: identification of a cell-surface protein involved in calcium-dependent cell aggregation. Cell 28: 217-224.

ZIMMERMANN, J., CAMLEY, B.A., RAPPEL, W.J. and LEVINE, H. (2016). Contact inhibition of locomotion determines cell-cell and cell-substrate forces in tissues. Proc Natl Acad Sci USA 113: 2660-2665 


\section{Further Related Reading, published previously in the Int. J. Dev. Biol.}

Focal adhesion kinase as a mechanotransducer during rapid brain growth of the chick embryo

Mary E. Desmond, Janice E. Knepper, Angela J. DiBenedetto, Elizabeth Malaugh, Sagrario Callejo, Raquel Carretero, Maria-Isabel Alonso and Angel Gato

Int. J. Dev. Biol. (2014) 58: 35-43

https://doi.org/10.1387/ijdb.130305md

Lateral inhibition and neurogenesis: novel aspects in motion

Pau Formosa-Jordan, Marta Ibañes, Saúl Ares and José-María Frade

Int. J. Dev. Biol. (2013) 57: 341-350

https://doi.org/10.1387/ijdb.120259jf

Michael Abercrombie (1912-1979)

R Bellairs

Int. J. Dev. Biol. (2000) 44: 23-28

http://www.intjdevbiol.com/web/paper/10761842

Conrad H. Waddington's contributions to avian and mammalian development, 1930-1940 C D Stern

Int. J. Dev. Biol. (2000) 44: 15-22

http://www.intjdevbiol.com/web/paper/10761841

Technique as the basis of experiment in developmental biology. An interview with Denis A.T. New

\section{Juan Arechaga}

Int. J. Dev. Biol. (1997) 41: 139-152

http://www.intjdevbiol.com/web/paper/9184323

From the laboratory to the patient and back - an interview with Marc Mareel Marc E. Bracke

Int. J. Dev. Biol. (2011) 55: 697-702

https://doi.org/10.1387/ijdb.113422mb

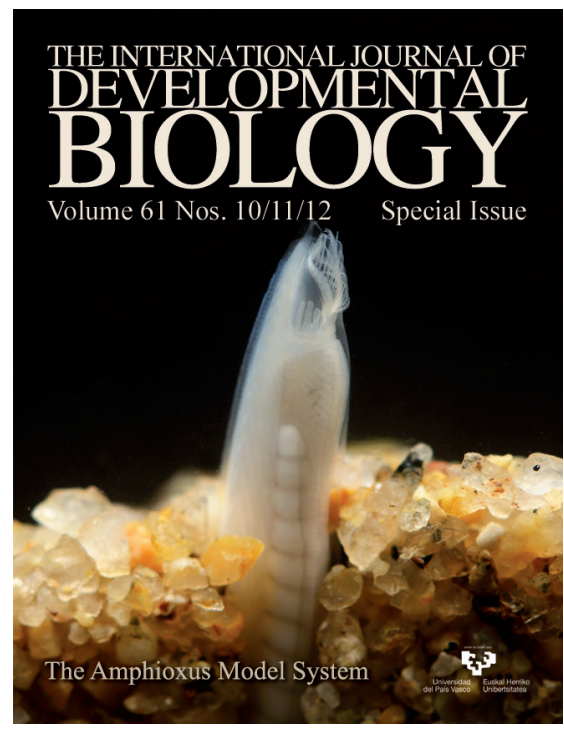

5 yr ISI Impact Factor $(2016)=2.421$
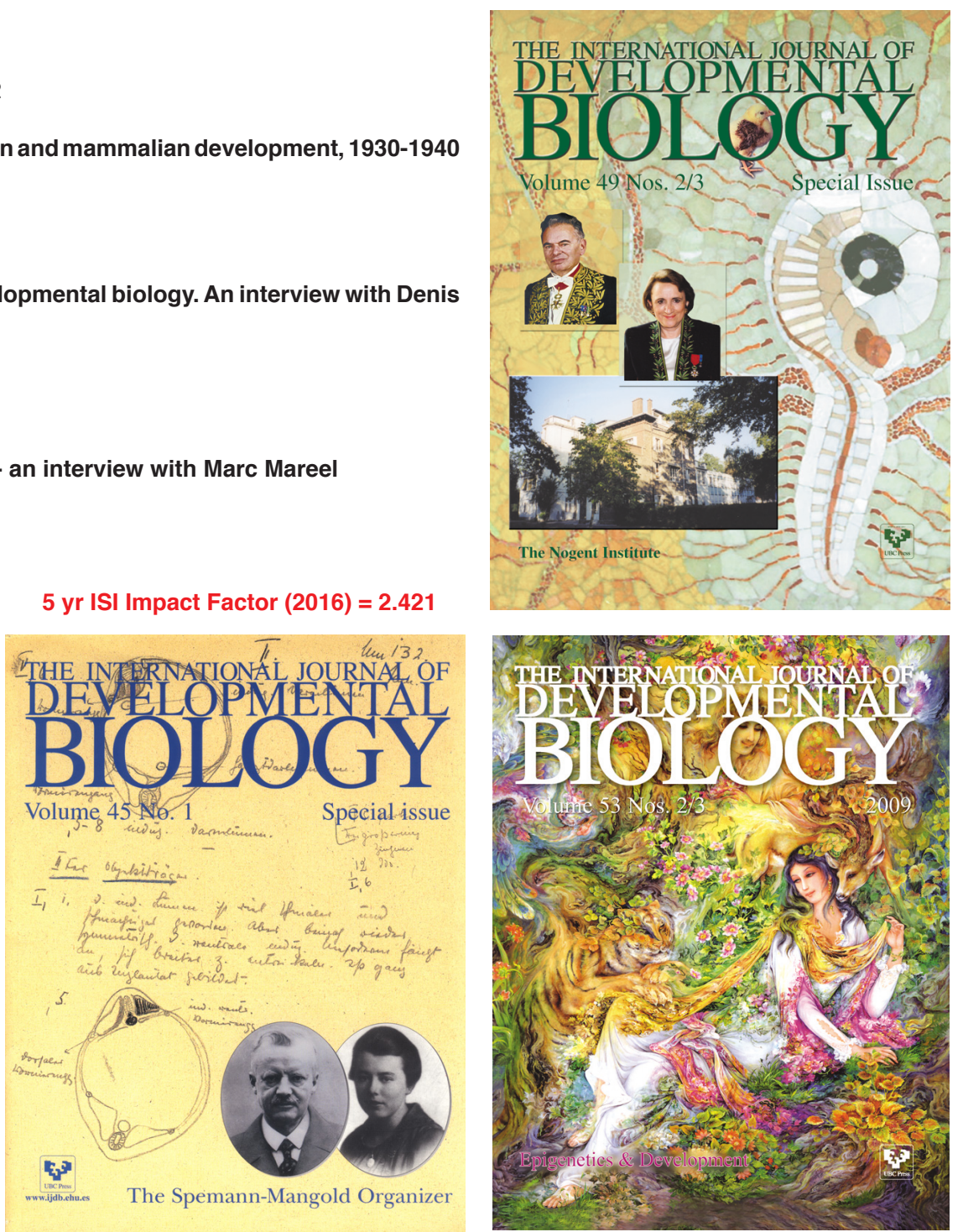